\title{
On Some Short Comings of the Transmission of Monetary Policy in the Euro Area
}

\author{
Antonino Tramontana \\ Center for Studies in Public Finance "Cesare Cosciani”, Rome, Italy
}

\begin{abstract}
The great expansionary policies undertaken by the main central banks of the world since the outbreak of the world financial and economic crisis in 2008 did not produce a satisfying recovery of the real economy especially in Europe. In order to identify the causes of this failure, it became necessary to deepen the analysis of the transmission mechanism of monetary policy, and to investigate if there are some obstacles hampering the functioning of this mechanism. The scope of the present papers to analyze some short comings of the transmission mechanism of the monetary policy is conducted by the European Central Bank (ECB) in the euro area. After a close examination of the relationship between the monetary base and the supply of money, transmission through the credit channel and through the interestrate channel will be taken into consideration. The analysis shows that loans to nonfinancial corporations were not affected by the huge amount of liquidity created by the ECB, while a very slow growth is shown by loans to private households during the whole period.
\end{abstract}

Keywords: base money, monetary aggregate, interest rate, credit channel, money market retail rate

\section{Introduction}

The original impulses of monetary policy are transmitted firstly to short term interest rates on wholesale money markets (EURIBOR rates in the euro area), then to longer term interest rates on the financial markets, to retail interest rates on the loans to nonfinancial corporations and households, and later to the demand for consumption and investment goods and services, to the level of prices, to the level of employment and wages in the labor market, and to foreign trade, foreign exchange, and so on (Angeloni, Kashyap, \& Mojon, 2003).

The transmission mechanism of monetary policy decisions was taken by central banks to the real economy operates mainly through two channels: the amount of credit which flows from credit institutions to nonfinancial firms and households and the prices applied on this credit, that is the interest rates applied to loans accorded to private borrowers.

The behavior of credit institutions which are counterparties of central banks in the monetary policy operations and lenders of money to private firms and households, is crucial for the more or less efficient functioning of the transmission mechanism of monetary policy.

The liquidity allotted by central banks is pushed in various direction by the banking systems, e.g. toward loans to financial institutions, loans to nonfinancial corporations or households, and purchase of government securities or other securities, maintained as cash or held in reserve or deposit accounts in central banks.

Antonino Tramontana, a former professor of public finance at the University of Perugia (Italy), Rome, Italy.

Correspondence concerning this article should be addressed to Antonino Tramontana, Viale Arrigo Boito 126, I-00199, Rome, Italy. 
Scope of the present paper is to analyze some shortcomings of the transmission of monetary policy conducted by the European Central Bank (ECB) to the variables of the real economy in the euro area after the outbreak of the world financial and economic crisis in year 2008 (European Central Bank, 2010).

Otherwise than in the economies of the United States and the United Kingdom, the role of banks is dominant in the financial systems of the euro area as providers of credit to the non-financial sectors of the economy; so their behaviour is of particular importance in the analysis of the transmission process of monetary policy and can hinder this process owing to their rigid capital, liquidity and reserve requirements, the great amount of nonperforming loans in their balance sheets, and the need to reduce their financial leverages after the crisis (King, 1986; Peek \& Rosengren, 1995).

The transmission mechanism of the monetary policy of the ECB will be examined firstly by an analysis of the relationship between the evolution of the monetary base and the evolution of the supply of money after the settlement of monetary policy operations and then by analyzing the effects of the impulses of monetary policy sent to the real economy through the credit channel and the interest rate channel.

\section{Monetary Base and the Supply of Money}

In order to analyze more clearly the transmission of monetary policy to the real variables of the economy in the euro area during and after the world economic and financial crisis which broke out in 2008, the first step is to investigate more deeply the evolution of the relationship between the monetary base (or base money) and the total supply of money in the euro area during the period.

The analysis will be carried out with reference to the monetary policy conducted by the European Central Bank (ECB) through open market operations, or performed on demand of counterparties (mainly credit institutions) using marginal lending and deposit facilities.

Standard operations of monetary policy of the ECB are conducted through the weekly Main Refinancing Operations (MROs), with maturity of one week, the monthly Longer Term Refinancing Operations (LTROs) ${ }^{1}$, originally with maturity of three months, and on demand of counterparties, the Overnight Lending and Deposit Facilities.

These operations influence the amount of reserves held by the banking systems with their National Central Banks (NCBs) - which are the main component of the monetary base $M 0$, composed by currency in circulation and funds held by banks in the Deposit and Reserve Accounts with the NCBs-but not directly the supply of money.

When liquidity is released by the ECB through open market or marginal lending operations, the supply of money, as measured by the money aggregates $M 1, M 2$, or $M 3$, can increase only as a consequence of further operations carried out by credit institutions which lend a part of the funds borrowed from the ECB to business firms, non-financial corporations, or households, thereby increasing their current bank accounts or the amount of currency in circulation ${ }^{2}$.

\footnotetext{
${ }^{1}$ For the structure of MROs and LTROs see: European Central Bank: The Monetary Policy of the ECB, 2011, pp. 104-110. After the crisis many LTROs with longer maturities were launched.

2 The European Central Bank defines three concepts of money aggregates: a narrow aggregate $M 1$, an intermediate one $M 2$, and a broad one $M 3$, differing with regard to the degree of liquidity of the assets they include. $M 1$ is defined as the sum of currency in circulation (banknotes and coins) and overnight deposits; $M 2$ comprises $M 1$ and deposits with an agreed maturity of up to two years or redeemable at a period of notice of up to three months; $M 3$ comprises $M 2$, repurchase agreements, money market fund shares, and debt securities with original maturity of up to two years (including money market paper). See: European Central Bank: The Monetary Policy of the ECB, 2011, p. 50.
} 
Instead, if credit institutions lend funds to other credit institutions through the interbank deposit markets or bilateral transactions or maintain in their deposit facility or current accounts with the NCBs the funds obtained through open market or marginal lending operations, the transfer of funds allotted by the ECB to credit institutions entails only an increase in the monetary base $M 0$, while the supply of money does not increase.

Because a great part of interbank transactions, as well as bank transactions with governments which hold their accounts with NCBs, are settled in monetary base, the amount of this base and its velocity of circulation can greatly influence short term interest rates and the prices of assets traded by banks, even without an appreciable increase in the supply of money, while the supply of money influences the quantities and prices of real consumer and investment goods, and services bought by business firms or households.

So it may happen that despite of a great allotment of funds to the banking systems, the supply of money, during a downturn of the business cycle or the stagnation of the economy, does not increase sensibly, being very low in the demand for credit by nonfinancial firms and households. But this demand can rise when it appears a better outlook of the conditions of the economic system, so inducing an increase in the money aggregate $M 3$ and there is the risk that a great part of the monetary base previously accumulated becomes money through a sudden rise of the demand for credit by nonfinancial firms and households: in this case, a rapid and strong increase in the supply of money can increase the rate of inflation.

So given the amount of bank reserves $R$, the supply of money $M 1, M 2$, or $M 3$ can be considered as a function of nominal total demand for goods and services or nominal gross domestic product at time $t: D(t)$ : in particular the relationship is as follows:

$$
M 3(t)=f(R, D(t)), \text { with } d M 3 / d D(t)>0
$$

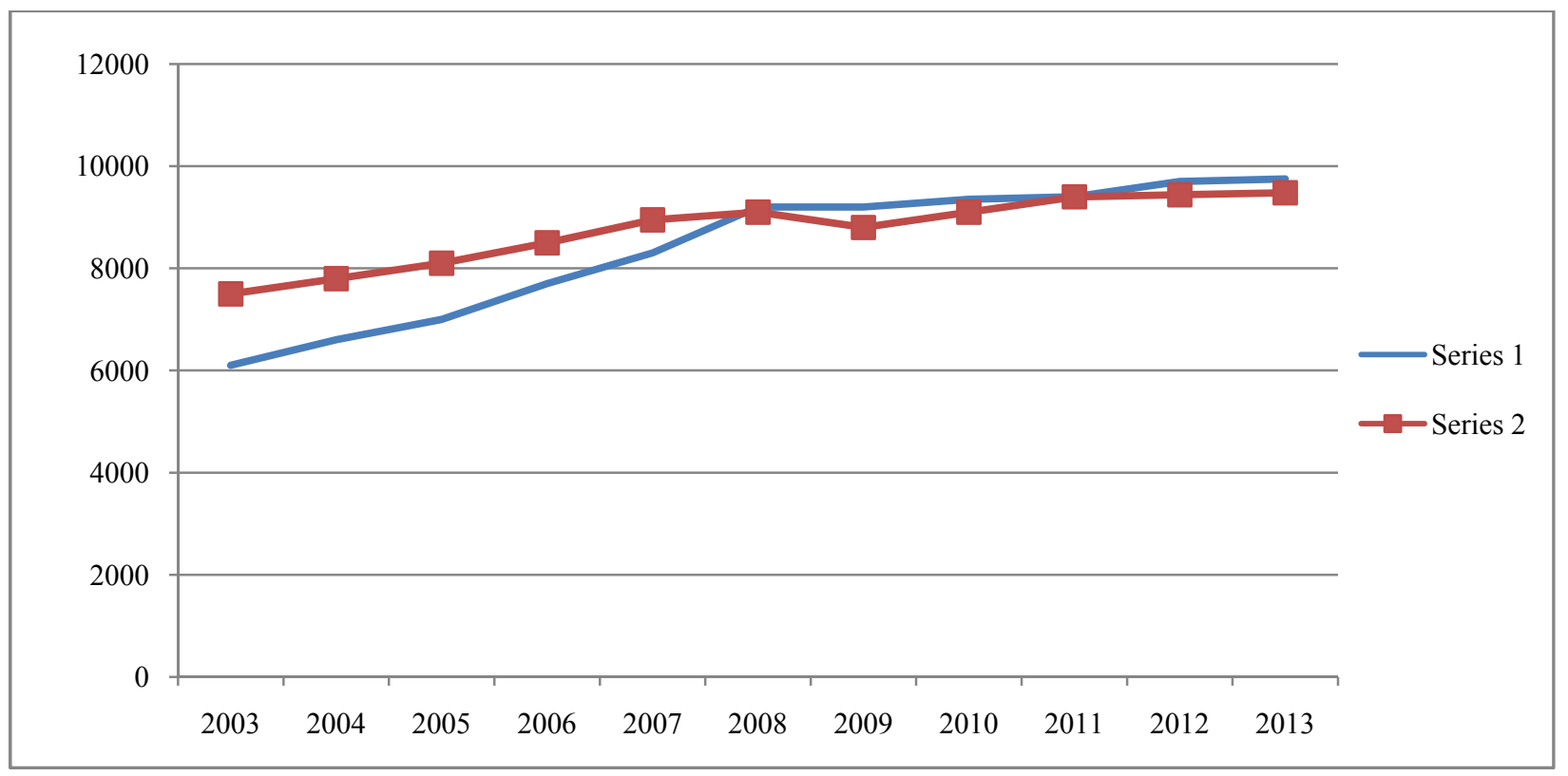

Figure 1. Monetary aggregate M3 and nominal GDP in the euro area in years 2003-2013 (billion euro). Notes. Series 1: Monetary aggregate $M 3$; Series 2: Nominal gross domestic product.

Figure 1, built on the statistical data contained in Table 1, shows the development of monetary aggregate M3 from year 2003 to 2013 compared with nominal Gross Domestic Product, while Table 2 reports the evolution of two main components of GDP, namely, Gross Fixed Capital Formation and Private Consumption 
from year 2004 to 2013.

In year 2008, for the first time, $M 3$ overtakes nominal GDP and exceeds it until 2013, so providing another evidence of the deepness and length of the economic depression in the euro area.

The divergence between the annual increase of the monetary base $M 0$ and that of aggregate $M 3$ is particularly relevant in year 2012 (Figure 2), owing to the two great LTROs, nearly 1,000 billion euro, launched in December 2011 and February 2012, at an interest rate of 1\% and with maturity of three years, as it can be clearly observed in Figure 2 below.

Figure 2 shows the annual increments in the monetary base $\Delta M 0$ and in the supply of money $\triangle M 3$ in the 12 months of year 2012 over the corresponding periods of the preceding year 2011.

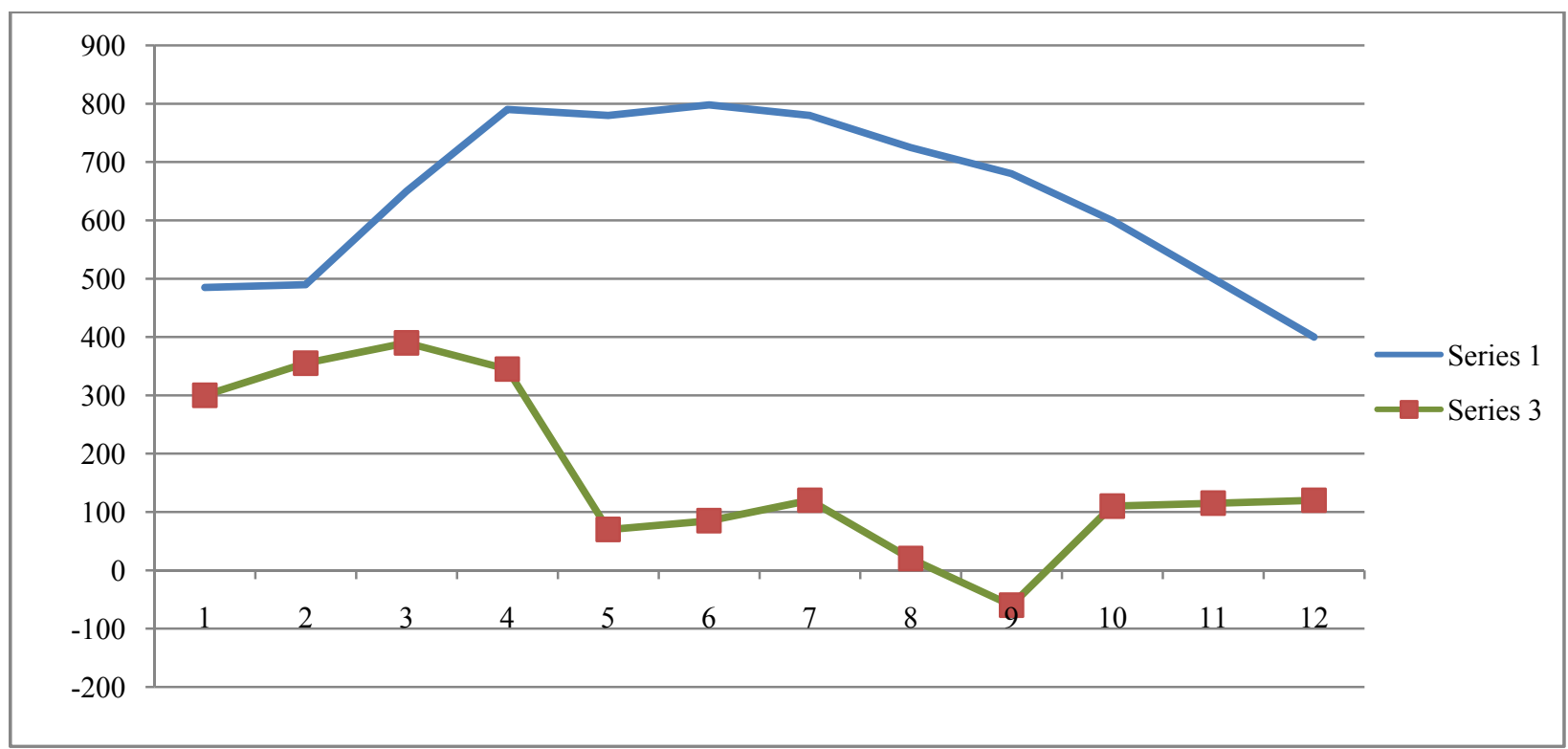

Figure 2. Increase of the monetary base $M 0$ and of money aggregate $M 3$ in year 2012 over the corresponding periods of the preceding year (data in blllion euro). Notes. Series 1: $\Delta M 0$; Series 3: $\Delta M 3$.

The course of both variables shows a certain lack of influence of the strongly expansionary measures undertaken in December 2011 and February 2012 on the supply of money M3.

Quite contrary to what one may expect, during the whole year, the increase in the monetary aggregate $M 3$ has been largely lower than the increase in the monetary base and resulted even negative in May and from July to October, so confirming the state of recession of the economy in the euro area.

But while an increase in monetary base does not necessarily induce an increase in a monetary aggregate, it is necessarily accompanied by an increase in the amount of securities offered as collateral in monetary policy operations, often derived by a securitization process of loans (Asset Backed Securities or ABS) and so by a creation of a class of risk transfer instruments ${ }^{3}$.

Therefore, the expansion of the monetary base may be considered as a powerful factor which stays behind the increase in the amount of Asset Backed Securities and other assets offered as collateral ${ }^{4}$, the increase in the

\footnotetext{
3 The amount of monetary base allotted in monetary policy operations is lower than the value of securities offered as collateral owing to the haircut applied on their face value.

${ }^{4}$ In the years preceding the outbreak of the crisis the issue of Asset Backed Securities in euro rose in the euro area from around $€ 50$ billion in 1999 to almost $€ 400$ billion in mid-2007. The notional amount outstanding in the global Credit Default Swap (CDS) market rose from virtually zero in 2001 to around USD 60 trillion at the end of 2007. See: European Central Bank (2008, p. 91).
} 
number of non-bank financial intermediaries issuers of securities (investment funds, insurance companies, pension funds, and credit cards operators), the increase in the financial leverages, the downfall of risk premia, the increase in the overall level of risk taking and in general the expansion of the financial sector, and the increase in the global degree of risk assumed by the economy (Rajan, 2005).

\section{Transmission Through the Credit Channel}

The impulses of monetary policy are transmitted to the real economy mainly by altering the availability of credit, that is the quantity of credit which flows from central banks through commercial banks to non-financial corporations and households (Credit Channel) and by altering the cost of credit through the variations in the rates of interest applied on borrowers (Interest Rate Channel) (Tables 3 and 4).

Firstly, the effect produced through the Credit Channel on the outstanding amount of the loans to the non-financial sectors of the economy is considered.

The outstanding amount of loans to non-financial corporations and households over the whole period 2008-2013 is described in Figures 3, 4, and 5, while Tables 3 and 4 below reported statistical data on these loans for the period.

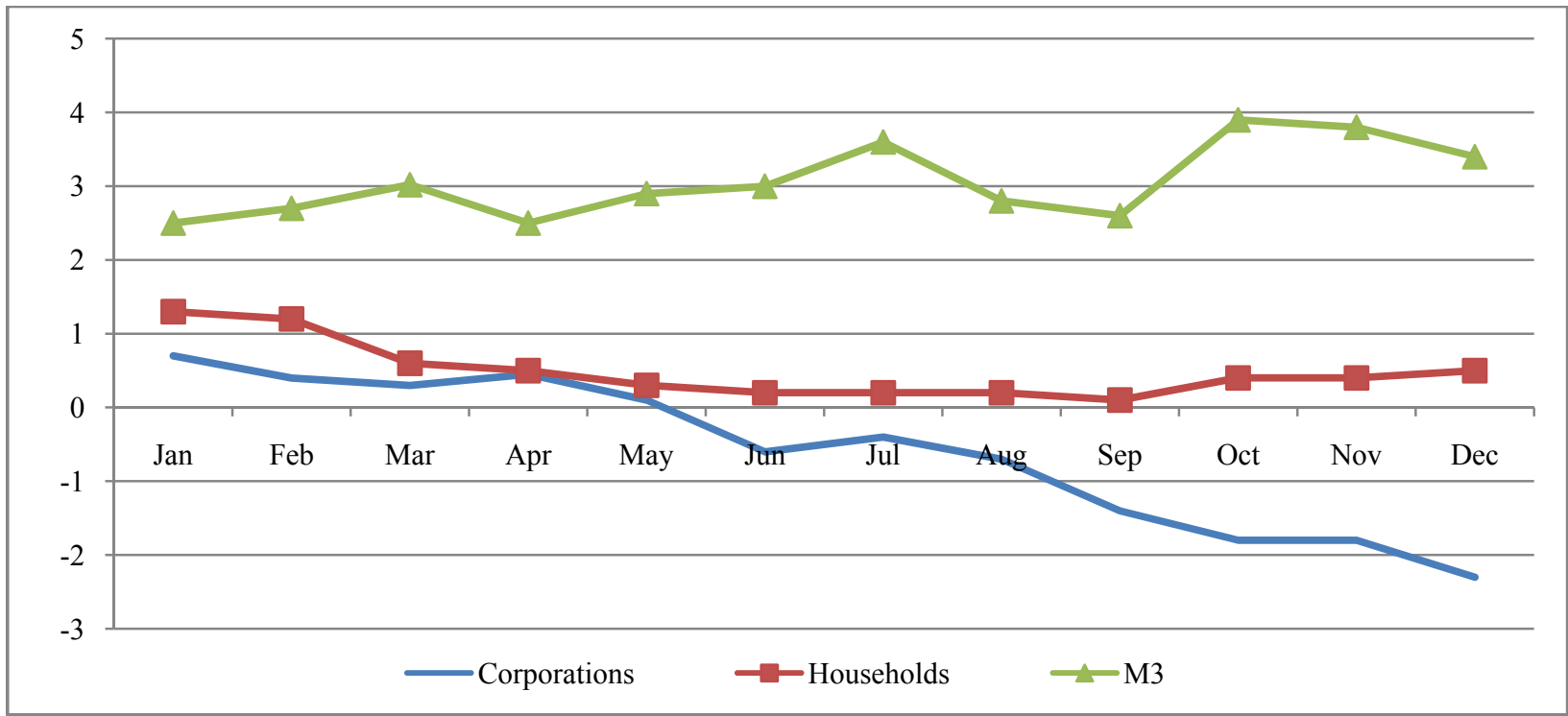

Figure 3. Percentage rates of growth of loans to non-financial corporations and households and of M3 in year 2012.

The great expansionary policy undertaken by the ECB in the years following the burst of the crisis, though conducted by an extraordinary mix of standard and non-standard operations, did not promote a stable recovery in the European real economy.

The financial crisis and the outlook of a serious downturn in the world economy entailed an increase in the default risk of enterprises and a tightening of terms and conditions for obtaining bank loans, causing a further slowing down in the process of adjustments of retail rates to the decrease of interbank rates ${ }^{5}$.

So it has been observed that "As the economy gradually improves, banks' capital bases are reinforced and their risk-taking behavior normalizes, it will be essential for banks to increase their lending activity" (European

\footnotetext{
${ }^{5}$ Sometimes the increase in the spreads applied to loans accorded to customers has, at least partly, offset the reduction in the EURIBOR rates.
} 
Central Bank, 2009).

Since the liquidity shortage has been more acute in longer maturities of the money market, the ECB has further enhanced the role of LTROs - already enlarged in the months immediately preceding the burst of the crisis - by lengthening the maturities of the operations and increasing the amount of liquidity allotted.

By means of these operations, the monetary policy of the ECB has been able to improve the general economic situation of credit institutions and to partly overcome the difficulties encountered by them on the wholesale money markets, particularly relevant because the crisis displayed first of all with an increase in interest rates and a reduction of the volume of exchanges on these markets.

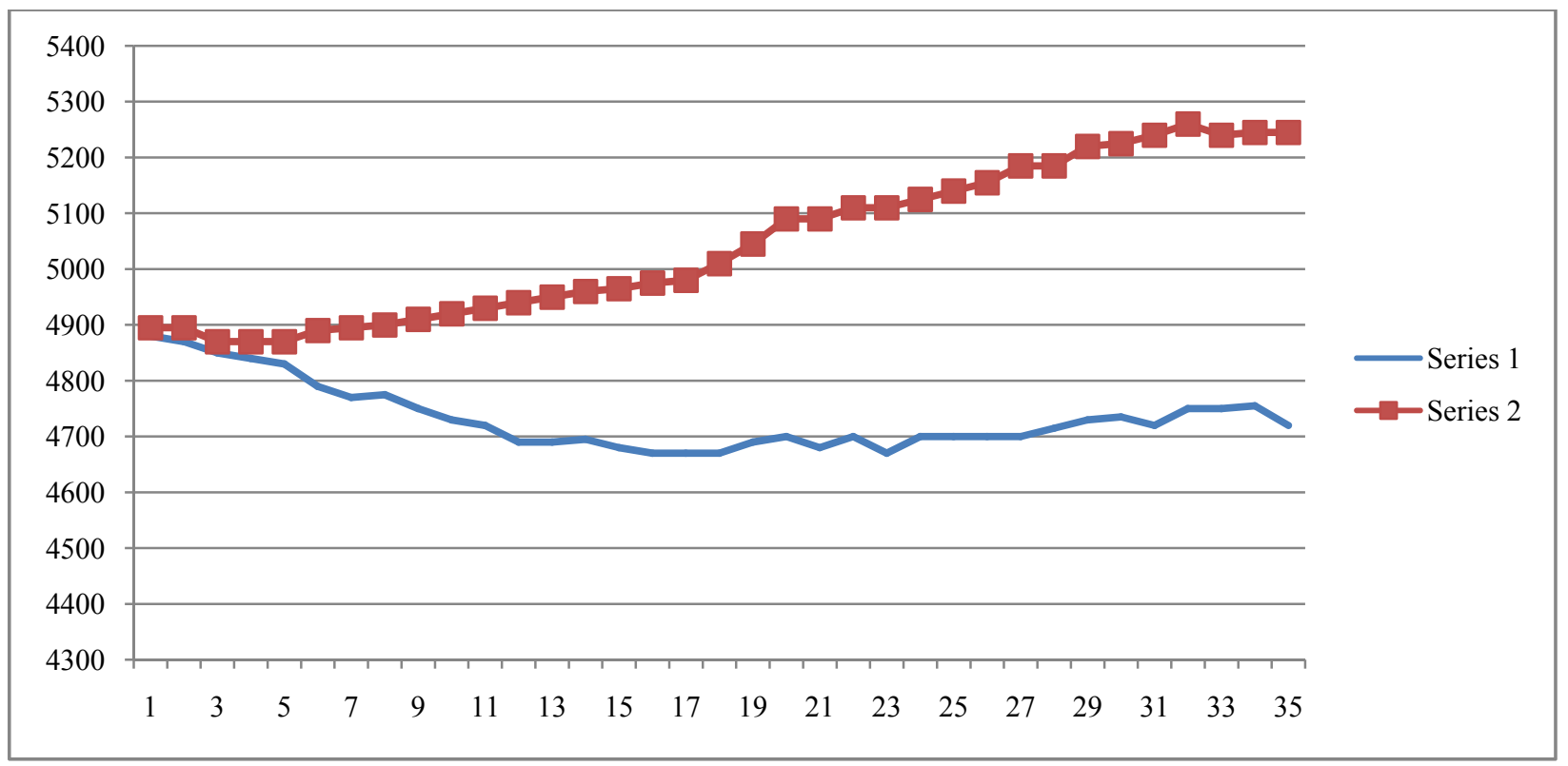

Figure 4. Loans to non-financial corporations and households in years 2009-2011 (billion euro). Notes. Series 1: Loans to non-financial corporations; Series 2: Loans to households.

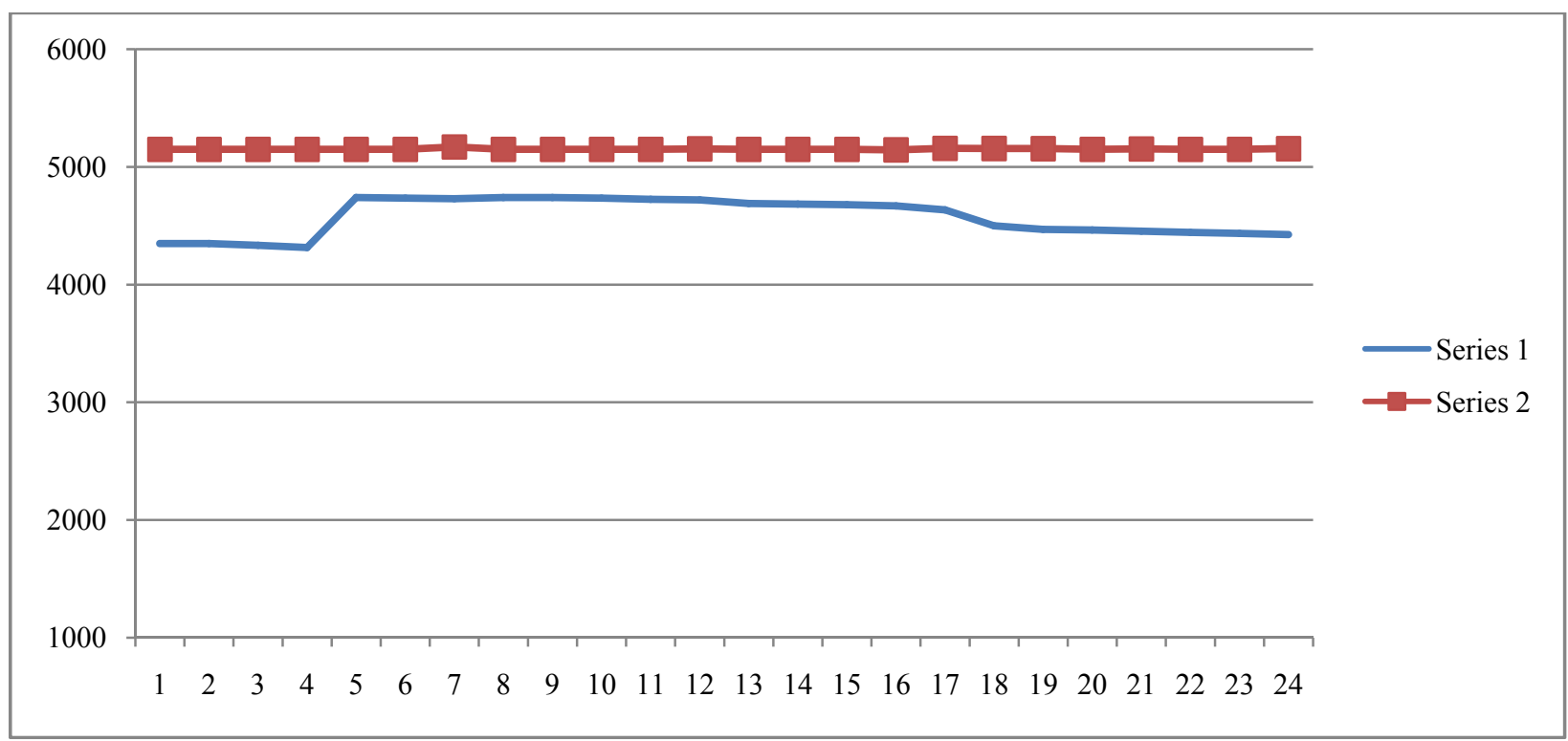

Figure 5. Loans to non-financial corporations and households in years 2012-2013 (billion euro). Notes. Series 1: Loans to non-financial corporations; Series 2: Loans to households. 
Table 1

Monetary Aggregate M3 and Nominal GDP in the Euro Area in Years 2003-2013 (Billion Euro)

\begin{tabular}{lll}
\hline Year & $M 3$ & GDP \\
\hline 2003 & $6,142.4$ & $7,486.0$ \\
2004 & $6,533.0$ & $7,809.6$ \\
2005 & $7,074.6$ & $8,143.9$ \\
2006 & $7,743.7$ & $8,558.5$ \\
2007 & $8,664.6$ & $8,995.5$ \\
2008 & $9,385.4$ & $9,267.4$ \\
2009 & $9,334.5$ & $8,919.8$ \\
2010 & $9,539.9$ & $9,185.8$ \\
2011 & $9,499.8$ & $9,444.0$ \\
2012 & $9,779.5$ & $9,505.4$ \\
2013 & $9,827.6$ & $9,602.5$ \\
\hline
\end{tabular}

Table 2

Year Gross Fixed Capital Formation Private Consumption (Billion Euro)

\begin{tabular}{lll}
\hline Year & Gross fixed capital formation & Private consumption \\
\hline 2004 & $1,578.3$ & $4,470.3$ \\
2005 & $1,673.6$ & $4,644.5$ \\
2006 & $1,834.4$ & $4,872.9$ \\
2007 & $1,970.5$ & $5,067.5$ \\
2008 & $1,989.2$ & $5,206.4$ \\
2009 & $1,730.6$ & $5,135.3$ \\
2010 & $1,741.2$ & $5,282.7$ \\
2011 & $1,796.6$ & $5,427.3$ \\
2012 & $1,744.8$ & $5,464.4$ \\
2013 & $1,698.3$ & 5,496 \\
\hline
\end{tabular}

Less effective has been the policy of credit supporting to the banking system in order to expand the volume of bank loans to nonfinancial corporations and households. Only in part, this increase has been realized and often there has been no increase at all. So the expansionary impact of this policy on the economic system as a whole has been reduced. Obviously, this policy cannot produce an expansionary effect similar to that of traditional fiscal policy which acts directly on the level of total demand for goods and services.

The banking systems, receiving great amounts of liquidity from the euro-system at a very low fixed rate of interest (presently at $0.25 \%$ ) even for maturity until three years, buy great amounts of low risk securities (especially government securities) which produce yields greater than $0.25 \%$ and so get very high profits. More risky loans to the private sector of the economy, constrained also by capital requirements of credit institutions, are discouraged and do not expand.

So the amount of credit to non-financial corporations and households, being limited by the capital requirement ratios of the lenders (recently strengthened by the Basel Three Agreement), is more easily the liquidity received by credit institutions invested in the purchase of government securities and other securities or deposited in the accounts held with the NCBs.

In 2009 , loans to non-financial corporations were sensibly and continuously reduced all over the year, while for households, the reduction was smaller and lasts until May, while a slow recovery appears in June. 
For non-financial corporations, the amounts of loans outstanding in November and December 2009 were, respectively, about 163 and 198 billion smaller than the amount outstanding in the preceding month of January and the annual growth rates are always decreasing and become negative in September. For households, the amount in August is only 1.4 billion greater than the amount in January, while the growth rates are decreasing until April and becoming negative in May and again in August and September. Only in November, there is a more sensible growth which brings the outstanding amount to a level higher by 32.4 billion euro than that of January, while in December the increase over the preceding January is 44.6 billion.

Even during 2010, the outstanding amount of loans accorded to non-financial corporations and firms marked an absolute decrease until April and after June; in December the amount was 20.1 billion euro lower than in the preceding January and 219.2 billion lower than that of January 2009, while the growth rates in the corresponding month of the preceding year remained negative all over the year and marked the maximum negative values $-2.7 \%$ and $-2.6 \%$ as shown in Table 3 respectively in the months of January and April.

Table 3

Loans to Nonfinancial Corporations in Years 2009-2013 (Billion Euro)

\begin{tabular}{|c|c|c|c|c|c|}
\hline Year & 2009 & 2010 & 2011 & 2012 & 2013 \\
\hline$\overline{\text { Jan }}$ & $4,884.6$ & $4,685.7$ & $4,699.5$ & $4,377.7$ & $4,638.5$ \\
\hline Feb & $4,880.0$ & $4,689.9$ & $4,705.7$ & $4,371.8$ & $4,636.8$ \\
\hline Mar & $4,848.3$ & $4,680.5$ & $4,705.4$ & $4,342.8$ & $4,542.0$ \\
\hline Apr & $4,840.8$ & $4,667.6$ & $4,700.5$ & $4,722.4$ & $4,530.7$ \\
\hline May & $4,827.3$ & $4,688.3$ & $4,717.8$ & $4,710.9$ & 4,511 \\
\hline Jun & $4,789.6$ & $4,689.5$ & $4,740.6$ & $4,699.3$ & $4,510.3$ \\
\hline Jul & $4,764.5$ & $4,664.7$ & $4,744.4$ & $4,703.1$ & $4,487.6$ \\
\hline Aug & $4,766.5$ & $4,686.3$ & $4,721.5$ & $4,703.7$ & $4,470.8$ \\
\hline Sep & $4,751.5$ & $4,699.6$ & $4,755.0$ & $4,697.8$ & $4,456.8$ \\
\hline Oct & $4,730.4$ & $4,685.1$ & $4,751.2$ & $4,703.6$ & $4,434.3$ \\
\hline Nov & $4,721.5$ & $4,698.3$ & $4,757.8$ & $4,667.1$ & $4,404.8$ \\
\hline Dec & $4,686.0$ & $4,665.2$ & $4,720.8$ & $4,653.3$ & $4,396.8$ \\
\hline
\end{tabular}

Table 4

Loans to Households in Years 2009-2013 (Billion Euro)

\begin{tabular}{|c|c|c|c|c|c|}
\hline Year & 2009 & 2010 & 2011 & 2012 & 2013 \\
\hline Jan & 4.898 .9 & $4,954.2$ & $5,182.3$ & $5,233.6$ & $5,244.6$ \\
\hline Feb & $4,899.2$ & $4,959.4$ & $5,184.4$ & $5,235.8$ & $5,252.8$ \\
\hline Mar & $4,889.6$ & $4,971.6$ & $5,217.6$ & $5,231.0$ & $5,254.1$ \\
\hline Apr & $4,888.1$ & $4,980.6$ & $5,225.7$ & $5,236.3$ & $5,243.5$ \\
\hline May & $4,887.2$ & $5,014.0$ & $5,242.2$ & $5,238.4$ & $5,238.5$ \\
\hline Jun & $4,891.2$ & $5,087.4$ & $5,262.5$ & $5,231.3$ & $5,249.1$ \\
\hline Jul & $4,892.7$ & $5,087.4$ & $5,259.2$ & $5,234.2$ & $5,237.8$ \\
\hline Aug & $4,900.3$ & $5,107.4$ & $5,264.0$ & $5,240.8$ & $5,231.5$ \\
\hline Sep & $4,909.9$ & $5,108.2$ & $5,275.3$ & $5,256.5$ & $5,241.5$ \\
\hline Oct & $4,918.9$ & $5,123.1$ & $5,233.8$ & $5,246.3$ & $5,233.0$ \\
\hline Nov & $4,931.3$ & $5,141.0$ & $5,243.1$ & $5,244.6$ & $5,227.6$ \\
\hline Dec & $4,943.5$ & $5,157.9$ & $5,242.8$ & $5,245.2$ & $5,238.2$ \\
\hline
\end{tabular}

The declining rate of growth of loans to non-financial corporations, keeps negative since May 2012 and the nearly 0 rate of growth of loans to households (Table 4) after the month of May, in contrast with positive 
and frequently growing rates of growth of the aggregate $M 3$, up to near $4 \%$ in October, which shows that the prevailing part of counterparties to the growth of $M 3$ was investments of liquidity other than loans to non-financial corporations and households, so confirming a certain lack of efficiency of the expansionary policy of the ECB for the recovery of the real economy in the euro area.

In 2013, loans to non-financial corporations show a further reduction in comparison with 2012, while loans to household appear practically unchanged.

The evolution of these loans over the whole period 2008-2013 is shown in Figures 4 and 5.

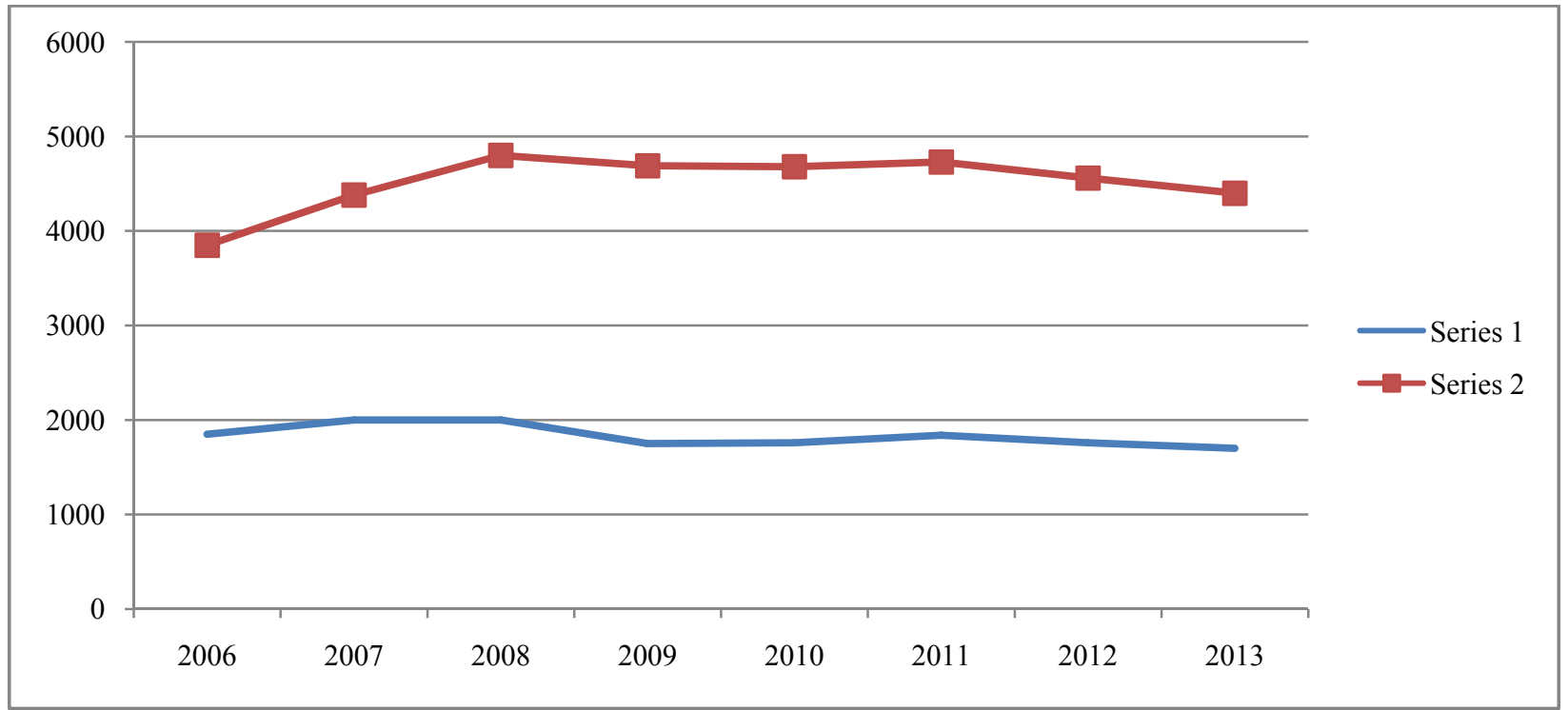

Figure 6. Gross fixed capital formation and loans to nonfinancial corporations of the euro area in the years 2006-2013 (data in billion euro). Notes. Series 1: Gross fixed capital formation; Series 2: Loans to nonfinancial corporations.

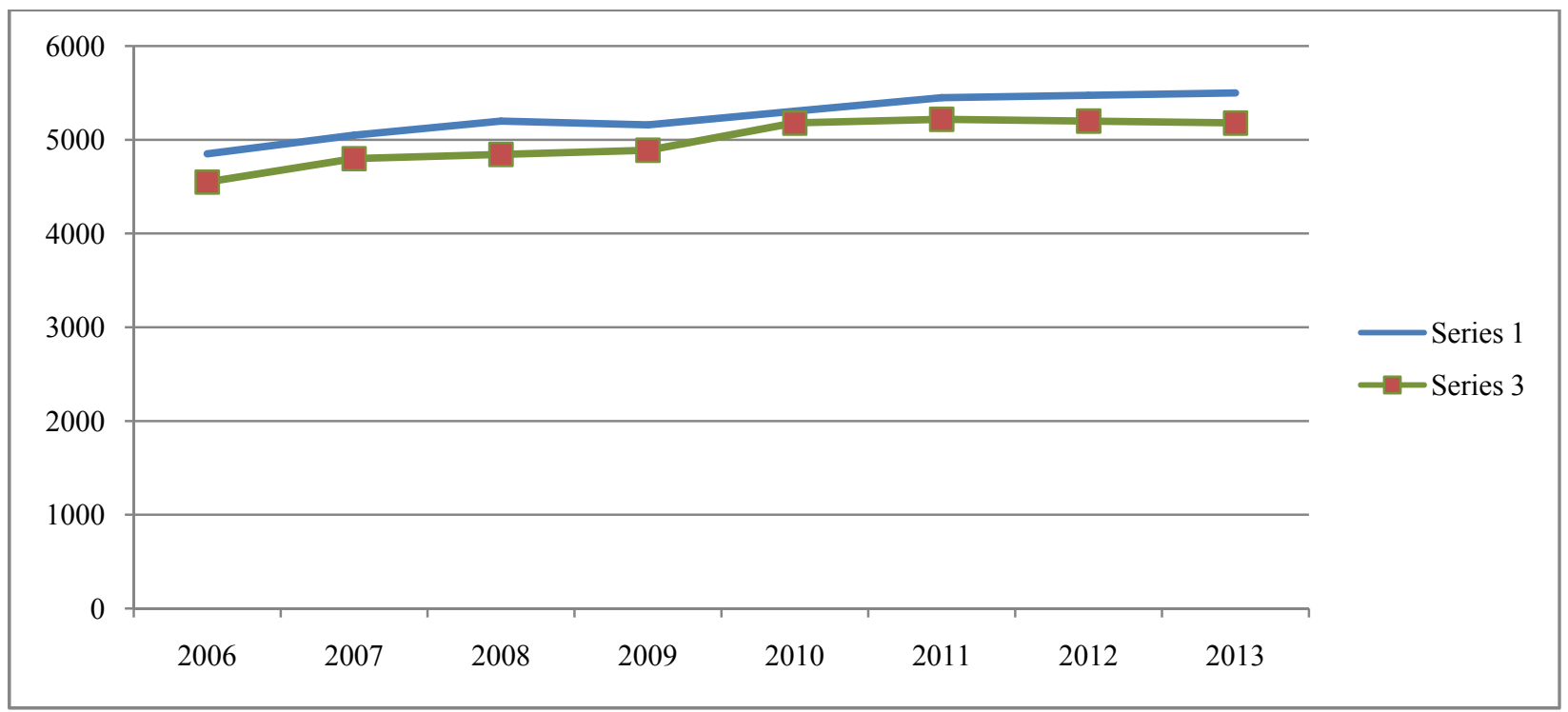

Figure 7. Private consumption and loans to households of the euro area in years 2006-2013 (data in billion euro). Notes. Series 1: Private consumption; Series 3: Loans to households.

During 2006-2013, a certain relationship can be found between the amount of loans to nonfinancial corporations and expenditures for gross fixed capital formation in the euro area, which were reduced after 2008, 
as can be seen from the graphic of Figure 6. A similar relationship holds between loans to households and the amount of private consumption in the same period can be seen from the graphic of Figure 7.

Both variables show a low rate of growth during the period.

\section{Transmission Through the Interest Rate Channel}

In the analysis of the transmission of monetary policy of the ECB through the interest rate channel, a clear distinction should be made between the transmission of the shifts of policy rates on short term wholesale euro money market rates and the influence of policy rates through money market rates on retail rates (de Bondt, 2005; Hoffmann \& Mizen, 2004).

In the first case, the transmission was very quick and effective, so that for most of the time, money market rates were squeezed very near and even below policy rates.

In the second case, the effects of the shifts of policy rates were partly offset by an increase of the spreads of retail rates over money market rates, so that the spreads between these two rates were increasing in the course of time.

The relationships between policy rates and money market rates will be taken firstly into consideration.

Statistical data on policy rates, money market rates, and retail rates for the years 2008-2013 are reported in Tables 5, 6, and $7 .^{6}$

Shifts in policy interest rates were normally followed by shifts in the same direction of short term interest rates on the wholesale money markets.

Table 5

Policy Rates, EURIBOR 3-m Rates and Retail Rates in Years 2008-2009 (\%)

\begin{tabular}{|c|c|c|c|c|c|c|}
\hline \multirow[b]{2}{*}{ Year } & \multicolumn{3}{|c|}{ Year 2008} & \multicolumn{3}{|c|}{ Year 2009} \\
\hline & Policy & EUR & Retail & Policy & EUR & Retail \\
\hline Jan & 4 & 4.48 & 5.93 & 2 & 2.46 & 4.73 \\
\hline Feb & 4 & 4.36 & 5.84 & 2 & 1.94 & 4.32 \\
\hline Mar & 4 & 4.6 & 5.91 & 1.5 & 1.64 & 4.03 \\
\hline Apr & 4 & 4.78 & 6.03 & 1.25 & 1.42 & 3.82 \\
\hline May & 4 & 4.86 & 6.1 & 1 & 1.28 & 3.73 \\
\hline Jun & 4 & 4.94 & 6.16 & 1 & 1.23 & 3.64 \\
\hline Jul & 4.25 & 4.96 & 6.26 & 1 & 0.97 & 3.56 \\
\hline Aug & 4.25 & 4.97 & 6.27 & 1 & 0.86 & 3.42 \\
\hline Sep & 4.25 & 5.02 & 6.34 & 1 & 0.77 & 3.36 \\
\hline Oct & 3.75 & 5.11 & 6.52 & 1 & 0.74 & 3.33 \\
\hline Nov & 3.25 & 4.24 & 6.04 & 1 & 0.72 & 3.34 \\
\hline Dec & 2.5 & 3.29 & 5.38 & 1 & 0.71 & 3.28 \\
\hline
\end{tabular}

Table 6

Policy Rates, EURIBOR 3-m Rates and Retail Rates in Years 2010-2011 (\%)

\begin{tabular}{lllllll}
\hline & \multicolumn{3}{c}{ Year 2010 } & \multicolumn{2}{c}{ Year 2011 } \\
\hline Year & Policy & EURIBOR & Retail & Policy & EURIBOR & Retail \\
\hline Jan & 1 & 0.68 & 3.25 & 1 & 0.68 & 3.25 \\
Feb & 1 & 0.66 & 3.25 & 1 & 0.66 & 3.25 \\
Mar & 1 & 0.64 & 3.24 & 1 & 0.64 & 3.24 \\
\hline
\end{tabular}

\footnotetext{
${ }^{6}$ All statistical data are drawn from the Monthly Bulletins of the European Central Bank.
} 
Table 6 continued

\begin{tabular}{|c|c|c|c|c|c|c|}
\hline$\overline{\mathrm{Apr}}$ & 1 & 0.64 & 3.19 & 1 & 0.64 & 3.19 \\
\hline May & 1 & 0.69 & 3.25 & 1 & 0.69 & 3.25 \\
\hline Jun & 1 & 0.73 & 3.25 & 1 & 0.73 & 3.25 \\
\hline Jul & 1 & 0.85 & 3.27 & 1 & 0.85 & 3.27 \\
\hline Aug & 1 & 0.9 & 3.38 & 1 & 0.9 & 3.38 \\
\hline Sep & 1 & 0.88 & 3.34 & 1 & 0.88 & 3.34 \\
\hline Oct & 1 & 1 & 3.44 & 1 & 1 & 3.44 \\
\hline Nov & 1 & 1.04 & 3.56 & 1 & 1.04 & 3.56 \\
\hline Dec & 1 & 1.02 & 3.5 & 1 & 1.02 & 3.5 \\
\hline
\end{tabular}

Table 7

Policy Rates, EURIBOR 3-m Rates and Retail Rates in Years 2012-2013 (\%)

\begin{tabular}{lllllll}
\hline & \multicolumn{2}{c}{ Year 2012 } & \multicolumn{2}{c}{ Year 2013 } \\
\hline Year & Policy & EURIBOR & Retail & Policy & EURIBOR & Retail \\
\hline Jan & 1 & 1.22 & 4.93 & 0.75 & 0.2 & 4.7 \\
Feb & 1 & 1.05 & 4.86 & 0.75 & 0.22 & 4.69 \\
Mar & 1 & 0.86 & 4.81 & 0.75 & 0.21 & 4.71 \\
Apr & 1 & 0.74 & 4.96 & 0.75 & 0.21 & 4.73 \\
May & 1 & 0.68 & 4.82 & 0.5 & 0.2 & 4.76 \\
Jun & 1 & 0.66 & 4.81 & 0.5 & 0.21 & 4.6 \\
Jul & 0.75 & 0.5 & 4.86 & 0.5 & 0.22 & 4.82 \\
Aug & 0.75 & 0.33 & 4.84 & 0.5 & 0.23 & 4.81 \\
Sep & 0.75 & 0.25 & 4.69 & 0.5 & 0.22 & 4.67 \\
Oct & 0.75 & 0.21 & 4.74 & 0.5 & 0.23 & 4.84 \\
Nov & 0.75 & 0.19 & 4.65 & 0.25 & 0.22 & 4.71 \\
Dec & 0.75 & 0.19 & 4.62 & 0.25 & 0.27 & 4.49 \\
\hline
\end{tabular}

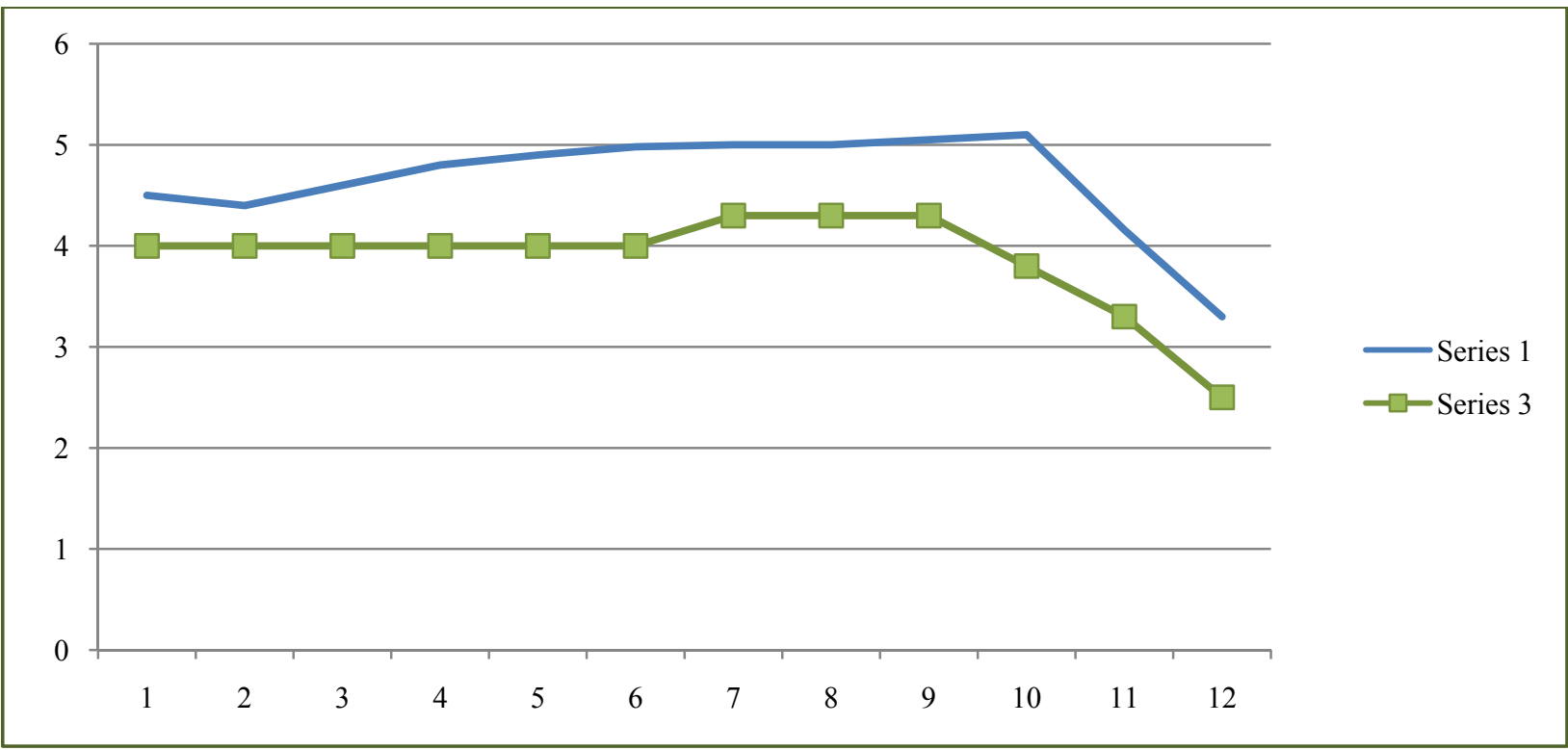

Figure 8. Policy rates and EURIBOR 3-m rates in year 2008. Notes. Series 1: EURIBOR 3-m rates (\%); Series 3:

Policy rates (\%) in year 2008.

The figures are considered as policy (or official) rates the interest rates (formerly minimum bid rates) applied on the Main Refinancing Operations (MROs) by the European Central Bank. As money market rates 
are considered rates applied on EURIBOR unsecured three-month loans, which may be considered as a benchmark of these markets for their particular relevance also for longer terms loans to nonfinancial corporations and households.

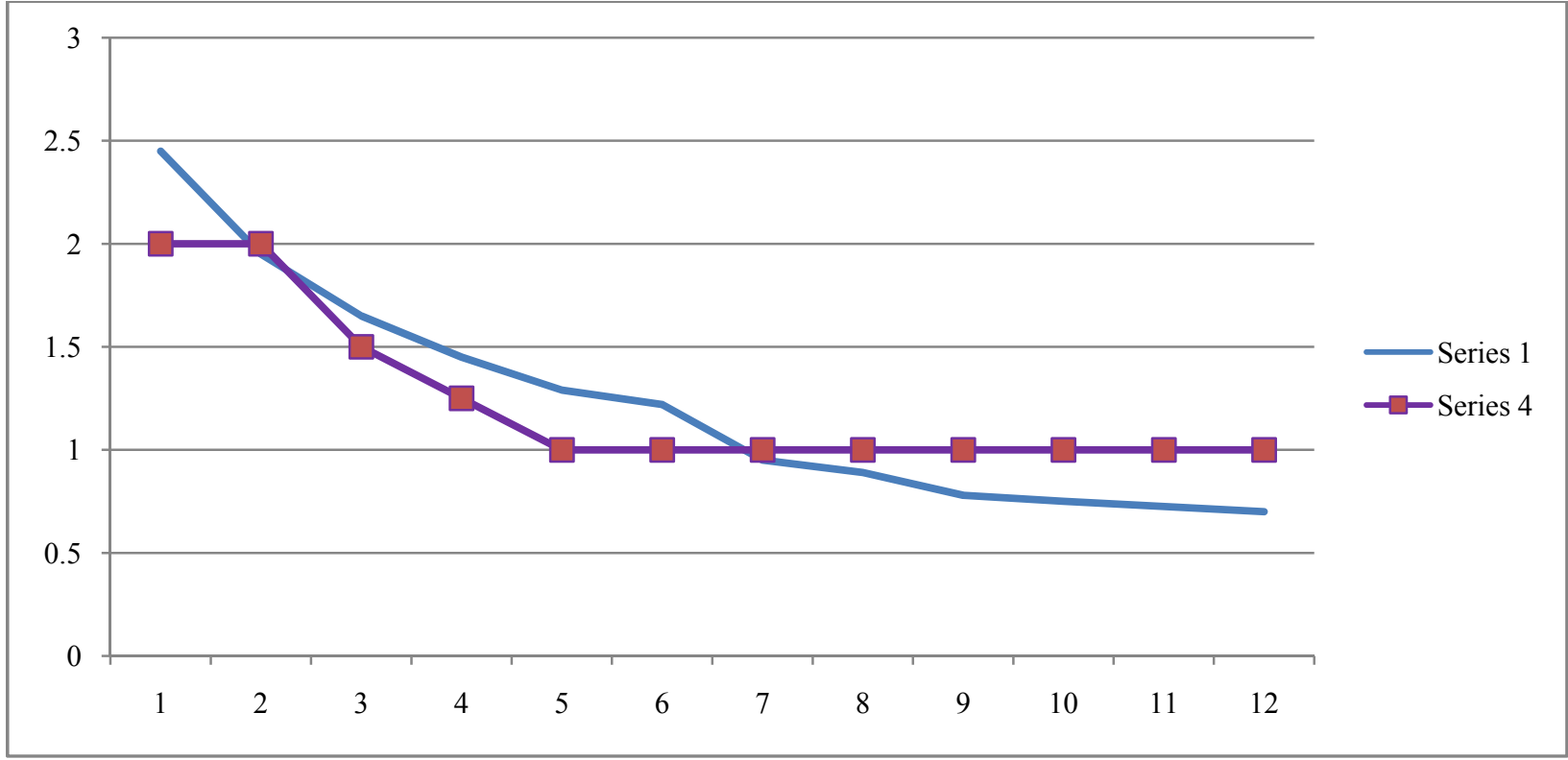

Figure 9. Policy rates and EURIBOR 3-m rates in year 2009. Notes. Series 1: EURIBOR 3-m rates (\%); Series 4: Policy rates (\%) in year 2009.

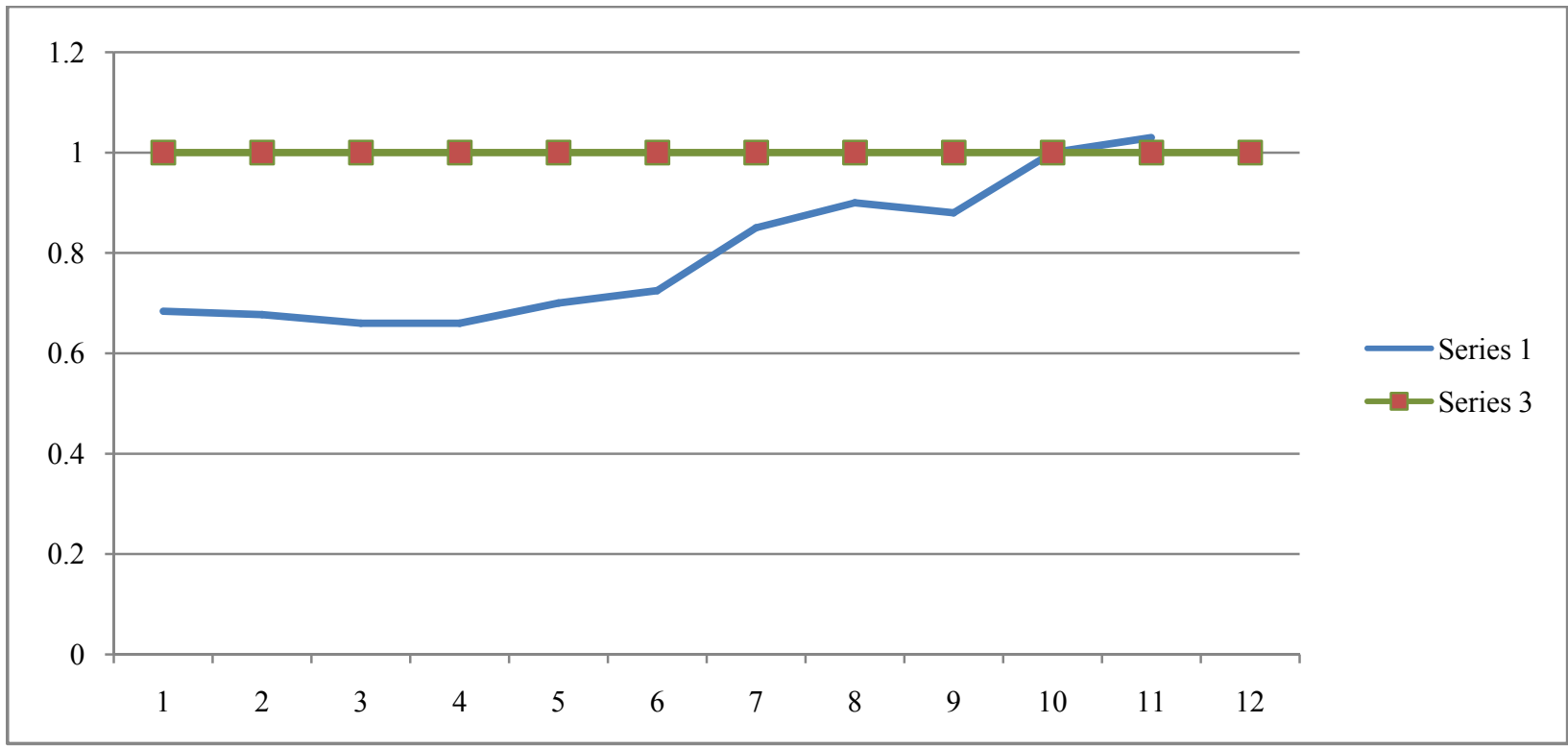

Figure 10. Policy rates and EURIBOR 3-m rates in year 2010. Notes. Series 1: EURIBOR 3-m rates (\%); Series 3: Policy rates (\%) in year 2010.

As is depicted in Figures 8 and 9, from the beginning of the year to September 2008, a sort of inflationary outlook seems still to dominate the money markets as well as the monetary authorities of the euro area, it can be seen from the light increase in the EURIBOR rates and the decision adopted in July by the ECB to increase from $4 \%$ to $4.25 \%$ the minimum bid rate on Main Refinancing Operations. But the outlook changed drastically 
in September after the Lehman bankruptcy: so in October and until May 2009, a series of reductions in ECB policy interest rates was very soon followed by a nearly parallel reduction in wholesale money market interest rates, which even fall under policy rates after July 2009.

After May 2009, policy rates were stabilized at the then historical minimum of $1 \%$, but EURIBOR rates in July fell below this rate and continued to fall until April 2010 (Figure 10); then a slow rise leads this rate to equal policy rates in October 2010.

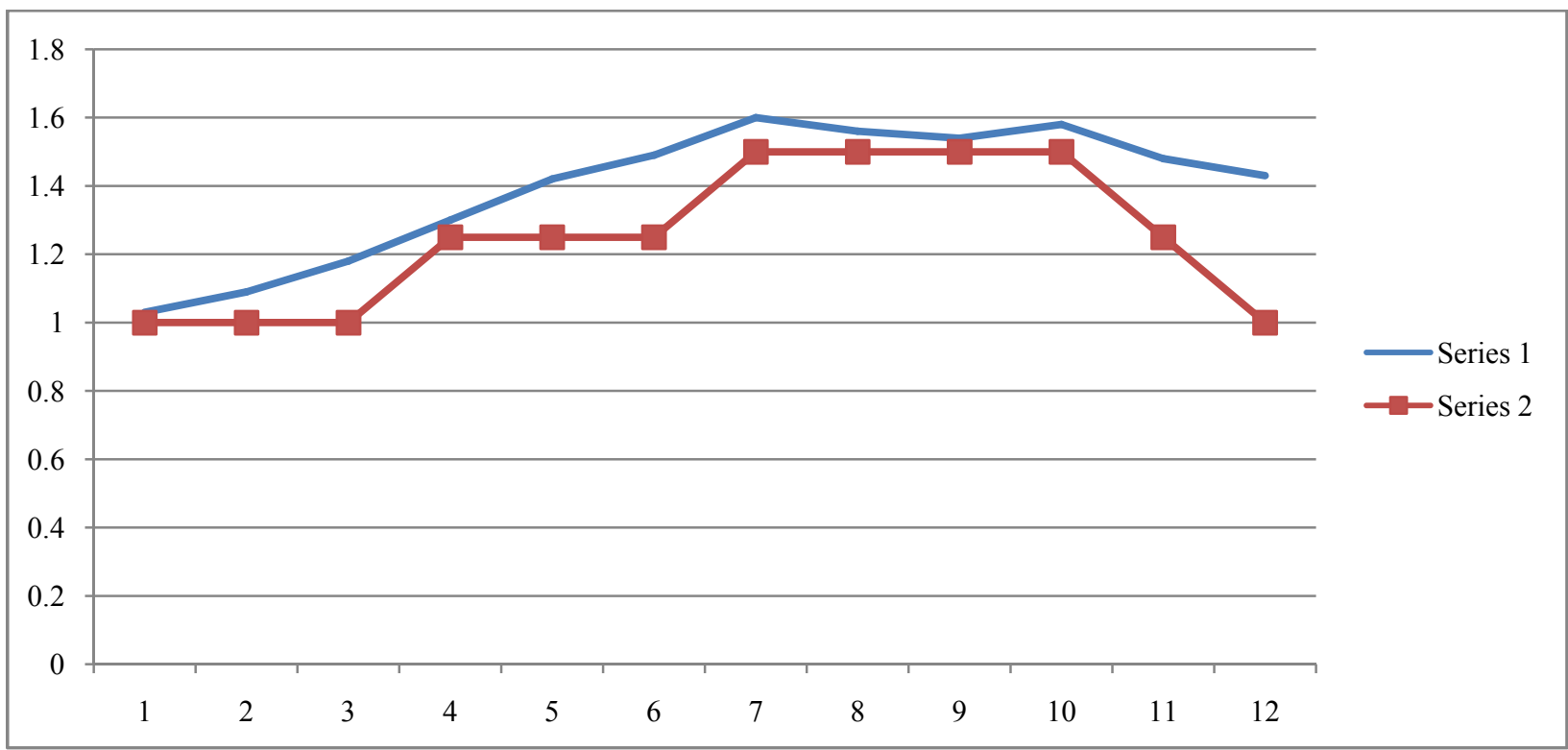

Figure 11. Policy rates and EURIBOR 3-m rates in year 2011. Notes. Series 1: EURIBOR 3-m rates (\%); Series 2:

Policy rates (\%) in year 2011.

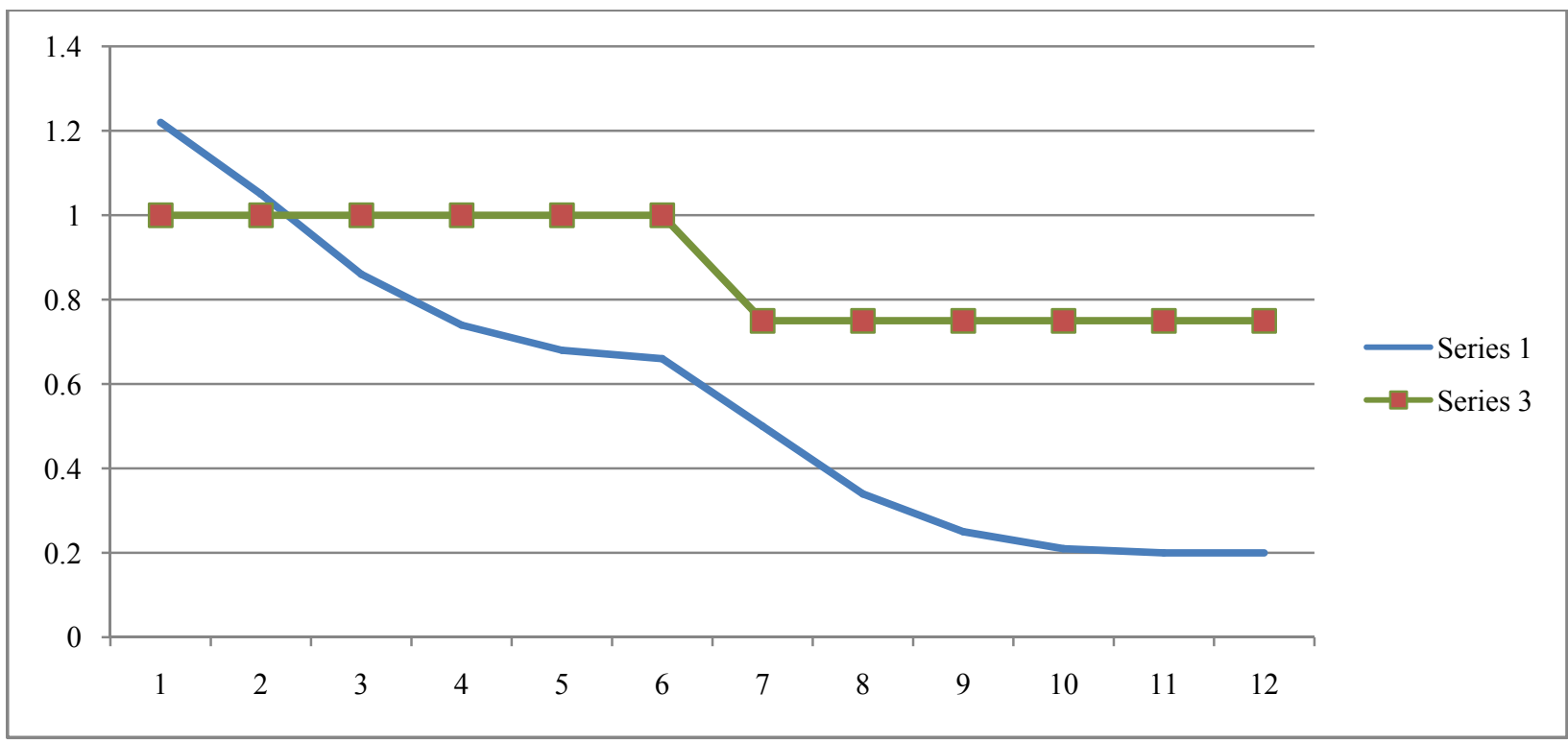

Figure 12. Policy rates and EURIBOR 3-m rates in year 2012. Notes. Series 1: EURIBOR 3-m rates (\%); Series 3: Policy rates (\%) in year 2012.

A return to normality seems to appear in 2011 (Figure 11), when EURIBOR rates are higher than policy rates in the whole year, and monetary policy seems to follow in successive increases, until October, the course 
of the money market, perhaps in the intent to forestall an overheating of the economy in the euro area; but the course of this policy is abruptly reversed in the last two months of the year, with two successive reductions of the policy rate after the appointment of the new President of the ECB Mario Draghi, perhaps owing to a downturn in the outlook of the economy (Kok Sørensen \& Werner, 2006).

Years 2012 and 2013 (Figures 12 and 13) witness a failure in the perspective of recovery and a down turn outlook of the economy in the euro area. Monetary policy of the ECB under the new direction seems well aware of the worsening of the economic situation and ready to act consequently, but from February 2012 to December 2013, despite of successive reductions in policy rates, which reach a new historical minimum at $0.25 \%$ in November 2013 , money market rates become again lower than policy rates.

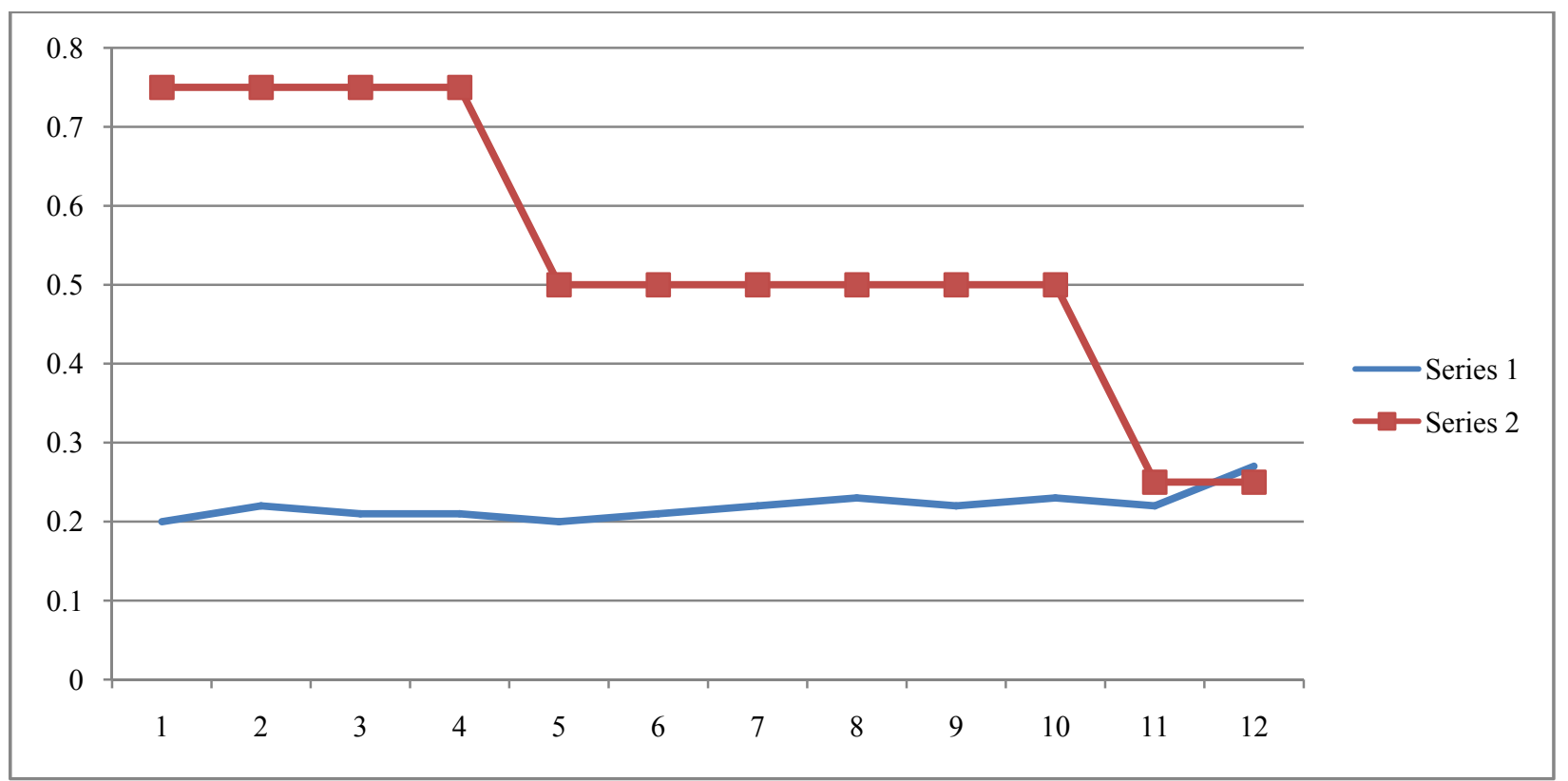

Figure 13. Policy rates and EURIBOR 3-m rates in year 2013. Notes. Series 1: EURIBOR 3-m rates (\%); Series 2:

Policy rates (\%) in year 2013.

Negative spreads of money market interest rates over policy rates from February 2012 onwards are a clear symptom of the economic depression and of malfunctioning of monetary markets during and after the crisis.

Less successful has been the transmission of the shifts in policy rates to the level of retail rates because these rates did not follow in the same measure, the fall in money market rates.

In the present paper, retail rates and the interest rates applied on loans to non-financial corporations with maturity of up to one year are considered.

The quick downward shift in money market rates which occurred between October 2008 and May 2009 was not followed by an equal parallel shift downward of retail rates applied on loans to nonfinancial corporations as can be seen in Figures 14 and 15 below.

Interest rates on loans to non-financial corporations and households may be considered as a function of the rates paid on marginal funding by banks and hence on interest rates occurring in the wholesale money markets; but evidently other elements also have influenced the behavior of banks in running the loans business.

In Figure 14, the curve describing the fall in retail rates after October 2008 is less steep than the curve describing money market rates and the spreads between the two rates gradually increase. 
Spreads between retail rates and EURIBOR three-month rates which were about $1.3 \%-1.5 \%$ in 2008 grew gradually but continuously over the years and attained levels about $4.5 \%$ in 2013 , when a lowering of money market rates to $0.25 \%$ in November was faced by a level of reatil rates about $4.7 \%$ to $4.8 \%$ over the year. Therefore, retail rates remained scarcely affected by the expansionary policy of the ECB, so producing a sort of procyclical effect in the years of the world crisis.

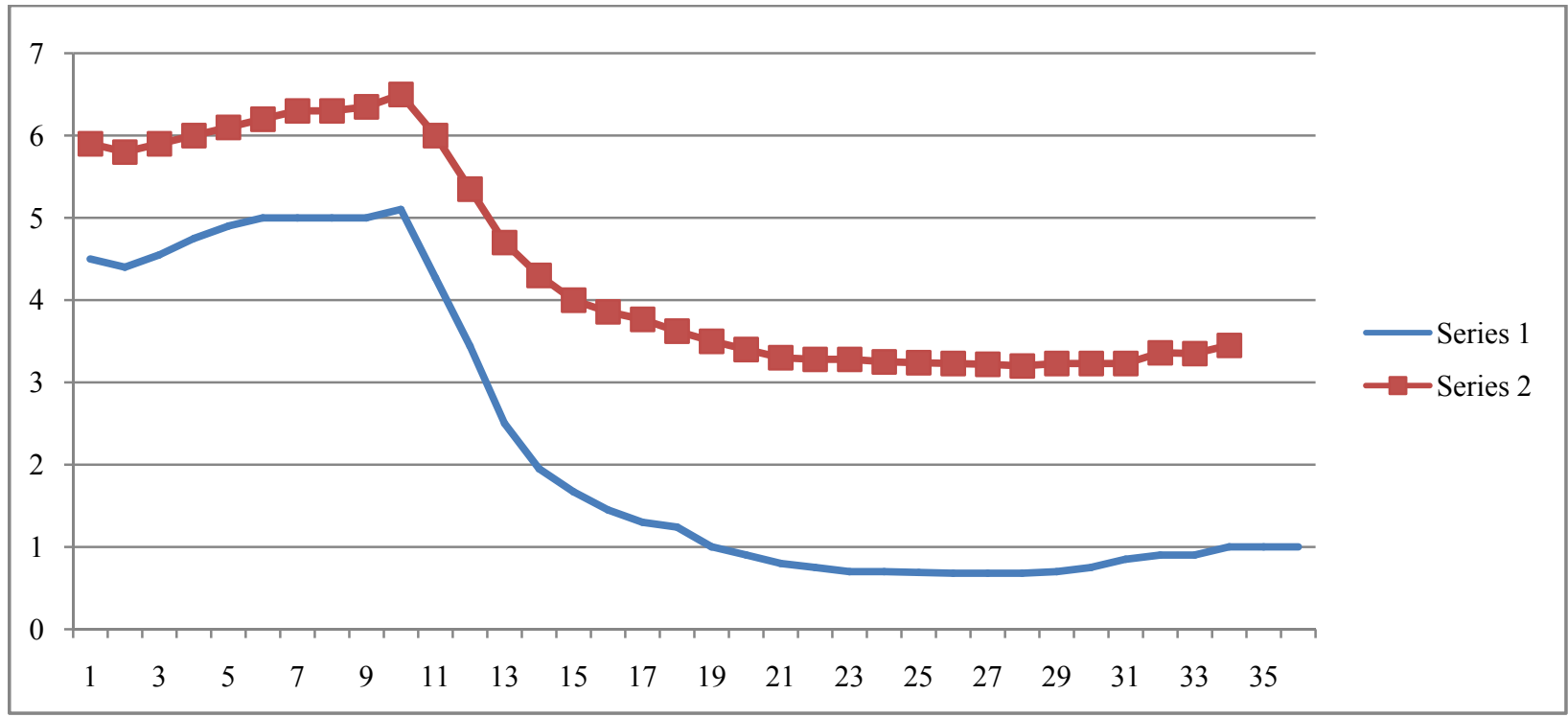

Figure 14. Percentage retail rates and money market rates in years 2008-2010. Notes. Series 1: Money market rates; Series 2: Retail rates.

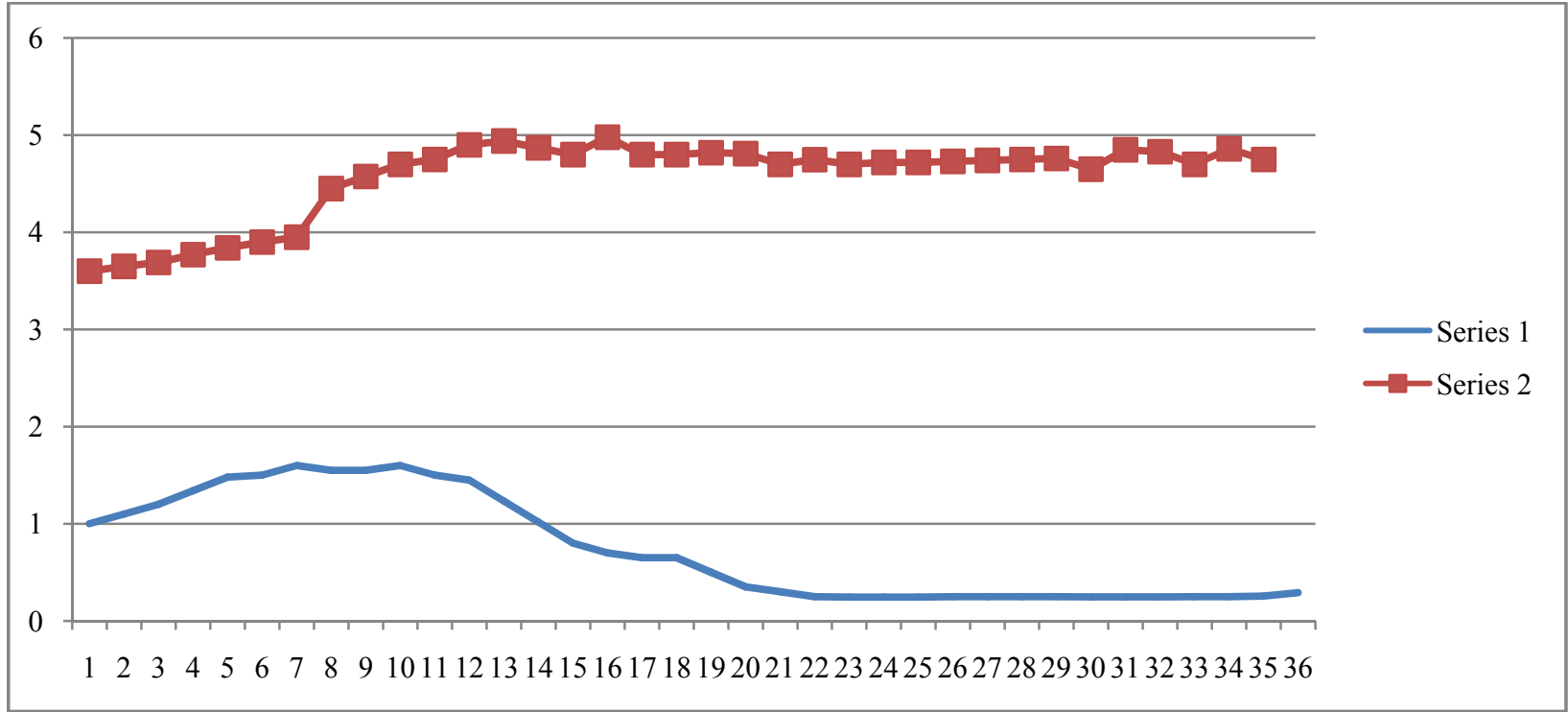

Figure 15. Percentage retail rates and money market rates in years 2011-2013. Notes. Series 1: Money market rates; Series 2: Retail rates.

\section{Concluding Remarks}

The analysis of the transmission of monetary policy to the real economy may start from the consideration that the monetary authority can regulate the volume of bank reserves with Central Banks, it repeated and 
demonstrated the divergence of the course of the monetary base and the supply of money, it represented by a narrow or an intermediate or a broad monetary aggregate.

Given the volume of reserves, the size of the supply of money $M 3$ is directly determined by factors affecting the demand for credit by non-financial firms and households.

Therefore, the great expansion occurred in the amount of bank reserves owing to the highly expansionary policy of the ECB in the years following the financial crisis of 2008, which did not entail a corresponding expansion in the supply of money, as measured by the growth of the aggregate $M 3$, nor a sensible growth in the outstanding amounts of credit to nonfinancial corporations and households in the euro area, because the demand for credit did not expand in proportion.

During and after the world crisis, the ECB has managed its strategy of monetary policy well beyond the achievement of the statutory target of maintaining price stability, maintaining its expansionary stance even with inflation rates higher than this target.

The lowering of nominal official interest rates to levels between zero and $1 \%$, with unlimited allotment of liquidity to the banking systems through temporary and outright open market operations and marginal lending facilities, entailing even negative real rates, while offering a certain support to the banking systems, was unable to transmit this expansionary impulse to the real economies of the area and to build a satisfactory "exit strategy" from the crisis, also owing to restrictive fiscal measures which have constrained total demand of goods and services and the demand and supply of money.

Moreover, for the banking systems as a whole, information and transaction costs for loans to the real sector of the economy are generally higher than costs of financial investments for the liquidity provided by the central bank. These facts may be considered as the first obstacle to the effectiveness of monetary policy for the recovery of the real economy.

The rate of growth of the monetary aggregate $M 3$, which in the years preceding the crisis, was largely and continuously higher than the reference value of $4.50 \%$, fell largely under this value after the outbreak of the crisis, assuming in some instances even negative values and runs also at present about $2 \%$.

The transmission of monetary policy to the real economy must be considered under two different aspects: the transmission through the credit channel and the transmission through the prices of credit, that is through the interest rates channel.

Under the first aspect, it must be noted that the outstanding amount of loans to nonfinancial corporations did not increase since 2008 at the beginning of the crisis and in some cases even decreased.

As may be noted in Table 3, the outstanding amount of loans to nonfinancial corporations was 4,884.6 billion euro in January 2009 and only 4,396.8 billion in December 2013, that is with a reduction of about 10 percent.

So the great amount of liquidity allotted by the ECB and received by the banking systems only in very small measure was lent to nonfinancial corporations and households, owing also to the level of capital requirements of the banks and to the amount of deteriorated credits accumulated in their balance sheets, but mainly utilized to purchasing government and other bonds, reimbursing own maturing obligations and laying funds in their deposit accounts with the NCBs.

The effects of the monetary policy conducted by the ECB through the channel of interest rates must be separately analyzed by examining the influence of policy rates on money market rates and the influence of the latter on retail rates.

The decisions of the ECB to reduce policy rates have been very effective for the reduction of money 
market rates, which after some time fell under policy rates, reaching values near to zero, but this fall hampered the functioning of these markets ${ }^{7}$.

Less Successful has been the transmission of monetary policy, through money market rates to the level of retail rates because these rates did not follow in the same measure, the fall in money market rates.

Spreads between retail rates and EURIBOR three month rates, which were about $1.3 \%-1.5 \%$ in 2008 , grew gradually but continuously over the years and attained levels about $4.5 \%$ in year 2013 .

Both the allocations of funds by banks to sector other than the financing of non-financial firms and the less effective lowering of retail rates in comparison with money market rates explain the relative inefficiency of monetary policy to achieve a satisfactory recovery of the real economy in Europe after the outbreak of the world crisis.

As has been noted, the sluggish response of lending rates to the policy interest rate reductions reflects differing perceptions of credit risk across countries and the effectiveness of monetary policy has been hindered also by the fragmentation of euro area credit markets enhanced by the crisis (European Central Bank, 2013).

\section{References}

Angeloni, L., Kashyap, A. K., \& Mojon, B. (2003). Monetary policy transmission in the euro area. Cambridge: Cambridge University Press.

de Bondt, G. J. (2005). Interest rate pass-through: Empirical results for the euro area. German Economic Review, 6(1), 37-78.

European Central Bank. (2008). The role of banks in the monetary policy transmission mechanism. Monthly Bulletin, August, 85-98.

European Central Bank. (2009). Recent developments in the retail bank interest rate pass-through in the euro area. Monthly Bulletin, August, 93-105.

European Central Bank. (2010). The ECB's monetary policy stance during the financial crisis. Monthly Bulletin, January, 63-71.

European Central Bank. (2013). Assessing the retail bank interest rate pass-through in the euro area at times of financial fragmentation. Monthly Bulletin, August, 75-91.

Hoffmann, B., \& Mizen, P. (2004). Interest rate pass-through and monetary transmission: Evidence from individual financial institutions' retail rates. Economica, 71, 99-123.

King, S. R. (1986). Monetary transmission: Through bank loans or bank liabilities. Journal of Money, Credit and Banking, 18, 290-303.

Kok Sørensen, C., \& Werner, T. (2006). Bank interest rate pass-through in the euro area. A cross-country comparison. Working Paper of the ECB, 580.

Peek, J., \& Rosengren, E. (1995). Is bank lending important for the transmission of monetary policy: An overview. Federal Reserve Bank of Boston Conference Series: Proceedings, 1-14.

Rajan, R. (2005). The financial development made the world riskier? National Bureau of Economic Research, working paper, No. 11728.

\footnotetext{
${ }^{7}$ Both in the euro area and in the United Kingdom wholesale money markets were severely affected by the crisis and by excessively expansionary monetary policies. Trading volumes on the unsecured overnight markets have fallen more than half since 2008. See: Bank for International Settlements: 82nd Annual Report, 1 April 2011-31 March 2012, Basel, 24 June 2012 , p. 46.
} 